\title{
Säilörehun ensi- ja jälkikasvun korjuuajan sekä väkirehutäydennyksen vaikutus lypsylehmien maidontuotantoon
}

\author{
Kaisa Kuoppala $^{1)}$, Marketta Rinne ${ }^{1)}$, Juha Nousiainen ${ }^{2)}$ ja Pekka Huhtanen ${ }^{1)}$ \\ ${ }^{1)}$ MTT, Kotieläintuotannon tutkimus, Eläinravitsemus, 31600 Jokioinen, etunimi.sukunimi@mtt.fi \\ ${ }^{2)}$ Valio Oy, Alkutuotanto ja jäsensuhteet, PL 10,00039 Valio, juha.nousiainen@valio.fi
}

\section{Johdanto}

Nurmiheinien ensikasvun korjuuajan vaikutus rehun syönti- ja tuotantopotentiaalin on erittäin suuri ja melko hyvin tunnettu (Rinne 2000). Säilörehun syönti lisääntyy keskimäärin $0,16 \mathrm{~kg}$ ka ja maitotuotos 0,3-0,5 kg päivässä, kun nurmisäilörehun D-arvo paranee $10 \mathrm{~g} / \mathrm{kg}$. Keskimääräisissä kasvuolosuhteissa alkukesällä nurmiheinien D-arvo huononee $5 \mathrm{~g} / \mathrm{kg}$ päivässä. Merkittävä osa karjatilan nurmirehusta valmistetaan nurmen jälkikasvusta, joten myös sen laadulla on suuri merkitys. Jälkikasvun laadun muutoksista ja rehun tuotantovaikutuksesta on huomattavasti vähemmän tutkimustietoa. Käytännön kokemukset ja epäsuorat koetulokset antavat aiheen epäillä, että vegetatiivinen jä lkikasvu on varsin toisentyyppistä rehua kuin generatiivinen ensikasvu. Rehun kemiallisen koostumuksen ja sulavuuden perusteella ei välttämättä pystytä arvioimaan rehun syöntiä, maitotuotosta ja väkirehutäydennystarvetta samojen periaatteiden mukaisesti kuin ensikasvussa.

Tässä kokeessa tuotettiin sulavuudeltaan selvästi toisistaan poikkeavia säilörehuja ensikasvussa ja jälkikasvussa. Tarkoituksena oli selvittää, vastaako sama D-arvo ensi- ja jälkikasvussa samaa syönti- ja maidontuotantovaikutusta, vaikuttaako D-arvon muutos syöntiin ja maidontuotantoon samalla lailla ensi- ja jälkikasvussa sekä saadaanko väkirehun lisäämiselle sama vaste säilörehun laadusta riippumatta.

\section{Aineisto ja menetelmät}

Koesäilörehuina oli kuusi kesällä 2002 tehtyä timotei-nurminatasäilörehua, joista kaksi oli ensikasvua ja neljä jälkikasvua. Nurmi lannoitettiin keväällä Kevätviljan Y1-lannoitteella (NPK 26-2-3) $370 \mathrm{~kg} / \mathrm{ha}$ ja toiselle sadolle annettiin Suomensalpietaria (NPK 26-0-1) $300 \mathrm{~kg} / \mathrm{ha}$. Ensikasvusäilörehut korjattiin 5.6. (aikainen ensikasvu, A) ja 17.6. (myöhäinen ensikasvu, M). Osa molemmista jälkikasvualoista korjattiin loppukesällä 29.7. (aikainen jälkikasvu eli rehut AA ja MA) ja osa 12.8. (myöhäinen jälkikasvu eli rehut AM ja MM). Säilörehut säilöttiin laakasiiloihin muurahaishappopohjaista säilöntäainetta käyttäen (AIV2Plus, 5,4 1/tonni). Nurmet niitettiin niittomurskaimella ja esikuivattiin lievästi (noin 4 h). Nurmien kehitystä seurattiin lisäksi ottamalla kasvustoista ruohonäytteet säilörehujen korjuun yhteydessä. Ruohonäytteet kerättiin peltolohkoille varatuilta $10 \times 40$ m kokoisilta koealoilta ottaen vähintään neljä $0,25 \mathrm{~m}^{2}: n$ kokoista n. $10 \mathrm{~cm}$ sänkeen leikattua osanäytettä. Ruohonäytteistä määritettiin kuiva-ainesato sekä botaaninen ja morfologinen koostumus.

Maidontuotantokokeessa oli 24 ay-rotuista lehmää, joiden poikimisesta oli kokeen alkaessa kulunut keskimäärin 68 vrk. Lehmät saivat säilörehua vapaasti ja väkirehua 8 tai $12 \mathrm{~kg} / \mathrm{pv}$. Väkirehuna oli monipuolinen teollinen seos. Koemallina oli cyclic change over. Lehmät jaettiin tuotoksen mukaan kahteen blokkiin. Kokeessa oli 4 kolmen viikon mittaista jaksoa, joista kunkin jakson viimeisen viikon rehunkulutus- ja tuotostietoja käytettiin tulosten laskemisessa. Dieettien sulavuudet määritettiin korkeampituottoisen blokin lehmiltä käyttäen merkkiaineena happoon liukenematonta tuhkaa (AIA). Maidon rasva-, valkuais- ja laktoosipitoisuudet määritettiin neljältä lypsykerralta otetuista näytteistä ja ureapitoisuus kahdelta lypsykerralta otetuista näytteistä. Lehmät punnittiin kokeen alkaessa ja jokaisen jakson lopussa kahtena peräkkäisenä päivänä. Rehu- ja sontanäytteet analysoitiin MTT:n Eläinravitsemuksen laboratoriossa standardimenetelmin. Säilörehujen D-arvo määritettiin pässeillä sonnan kokonaiskeruumenetelmällä. ME-, RY-, OIV- ja PVT-arvot laskettiin rehutaulukon kaavoilla (Tuori ym. 2002) käyttäen pässeillä määritettyä D-arvoa. Sulamattoman NDF:n (INDF) pitoisuus määritettiin inkuboimalla rehunäytteitä 12 vrk karkearehuvaltaisella ruokinnalla olevan lehmän pötsissä (nailonpussin silmäkoko $17 \mu \mathrm{m})$.

Tulokset analysoitiin tilastollisesti SAS GLM proseduurilla. Mallissa oli mukana blokki, eläin, jakso, ruokinta, ruokinnan jälkivaikutus sekä ruokinta $\times$ blokki ja jakso $\times$ blokki -yhdysvaikutukset. Ruokinnan jälkivaikutusta ei otettu malliin mukaan analysoitaessa sulavuustuloksia. Ruokinnan vaikutus jaettiin ortogonaalisin kontrastein sadon vaikutukseen (ensikasvu vs. jälkikasvu), kasvuasteen vaikutukseen molemmissa sadoissa sekä jälkikasvurehujen vertailuun. 


\section{Tulokset ja tulosten tarkastelu}

\section{Rehujen koostumus ja sato}

Hehtaarisato suureni korjuun viivästyessä ensikasvussa $131 \mathrm{~kg} / \mathrm{pv}$ ja jälkikasvussa $124 \mathrm{~kg} / \mathrm{pv}$. Kasvusto oli suurimmaksi osaksi timoteita, sillä timotein osuus kasvustosta oli keskimäärin 0,844 ensikasvussa ja 0,734 jälkikasvussa.

Taulukko 1. Rehujen koostumus ja säilörehujen käymislaatu

\begin{tabular}{|c|c|c|c|c|c|c|c|}
\hline & A & $\mathrm{M}$ & AA & $\mathrm{AM}$ & MA & MM & Väki- \\
\hline Korjuupäivä v. -02 & 5.6. & 17.6. & 29.7. & 12.8. & 29.7. & 12.8. & rehu \\
\hline Sato & 1 & 1 & 2 & 2 & 2 & 2 & \\
\hline Ensikasvu korjattu & & & 5.6. & 5.6. & 17.6. & 17.6. & \\
\hline Sato, kg ka/ha ${ }^{1)}$ & 4165 & 5742 & 4618 & 6202 & 3714 & 5614 & \\
\hline Timotein osuus ${ }^{1)}$ & 0,837 & 0,850 & 0,728 & 0,763 & 0,738 & 0,708 & \\
\hline \multicolumn{8}{|l|}{ Lehtien osuus $^{1)}$} \\
\hline Timoteissä & 0,489 & 0,340 & 0,503 & 0,390 & 0,639 & 0,529 & \\
\hline Nurminadassa & 0,538 & 0,491 & 0,769 & 0,711 & 0,794 & 0,801 & \\
\hline Kuiva-ainetta, g/kg & 274 & 283 & 235 & 323 & 230 & 320 & 862 \\
\hline \multicolumn{8}{|l|}{ Kuiva-aineessa, g/kg ka } \\
\hline Tuhka & 83 & 68 & 97 & 92 & 97 & 86 & 80 \\
\hline Raakavalkuainen & 160 & 127 & 146 & 115 & 159 & 130 & 179 \\
\hline Solunseinäkuitu (NDF) & 498 & 594 & 534 & 541 & 518 & 530 & 256 \\
\hline Sulamaton NDF (INDF) & 50,3 & 97,2 & 70,5 & 93,3 & 59,8 & 79,1 & 50,9 \\
\hline Etikkahappo & 17 & 12 & 17 & 10 & 18 & 9 & \\
\hline Propionihappo & 0,6 & 0,2 & 0,1 & 0,1 & 0,2 & 0,1 & \\
\hline Voihappo & 1,55 & 0,94 & 0,65 & 0,58 & 1,16 & 0,19 & \\
\hline Maitohappo & 68,4 & 36,9 & 60,8 & 31,3 & 67,5 & 28,2 & \\
\hline Sokeri & 34,0 & 94,1 & 28,6 & 127,3 & 26,0 & 126,1 & \\
\hline \multicolumn{8}{|l|}{ g/kg kokonais-N } \\
\hline Ammonium-N & 47 & 61 & 60 & 70 & 58 & 62 & \\
\hline Liukoinen N & 614 & 607 & 491 & 512 & 522 & 499 & \\
\hline $\mathrm{pH}$ & 4,11 & 4,23 & 4,07 & 4,45 & 4,10 & 4,47 & \\
\hline D-arvo, g/kg ka & 704 & 644 & 659 & 609 & 664 & 629 & \\
\hline $\mathrm{RY} / \mathrm{kg} \mathrm{ka}$ & 0,96 & 0,88 & 0,90 & 0,83 & 0,91 & 0,86 & $1,06^{2)}$ \\
\hline $\mathrm{OIV}, \mathrm{g} / \mathrm{kg} \mathrm{ka}$ & 85,4 & 77,0 & 79,8 & 72,7 & 81,4 & 75,8 & $109,2^{2}$ \\
\hline Syönti-indeksi & 102 & 94 & 94 & 89 & 95 & 92 & \\
\hline
\end{tabular}

Kaikki säilörehut olivat säilönnälliseltä laadultaan hyviä (keskimääräinen pH 4,24 ja ammoniumtypen osuus kokonaistypestä $60 \mathrm{~g} / \mathrm{kg} \mathrm{N}$ ). Säilörehun valkuaispitoisuus pieneni tyypillisesti kasvun edetessä. Ensimmäisessä sadossa valkuaispitoisuus pieneni $2,8 \mathrm{~g} / \mathrm{kg}$ ka päivässä (A->M) ja jälkikasvussa $2,1 \mathrm{~g} / \mathrm{kg}$ ka päivässä (AA->AM ja MA->MM keskimäärin). Solunseinäkuitupitoisuus (NDF eli neutraalidetergentti kuitu) lisääntyi ensikasvussa selvästi ( $8,1 \mathrm{~g} / \mathrm{kg}$ ka päivässä) korjattaessa säilörehu myöhemmin, mutta jälkikasvussa solunseinäkuitupitoisuus lisääntyi vain vähän $(0,7 \mathrm{~g} / \mathrm{kg}$ ka päivässä). Jälkikasvurehujen solunseinäkuitupitoisuus oli keskimäärin pienempi kuin ensikasvurehujen. Sulamatonta solunseinäkuitua (INDF) jälkikasvurehuissa oli keskimäärin hieman enemmän kuin ensikasvurehuissa. INDF:n pitoisuus lisääntyi korjuun viivästyessä 3,9 g/pv ensikasvussa ja keskimäärin $1,5 \mathrm{~g} / \mathrm{pv}$ jälkikasvussa.

Ensikasvussa korjuun viivästyminen huononsi säilörehun D-arvoa keskimäärin 5,0 g /vrk, joka on samaa tasoa kuin aiemmissa aineistoissa (mm. Rinne ym. 1999, Rinne ym. 2002). D-arvo huononi myös toisessa sadossa, kun korjuu viivästyi (AA->AM 3,6 g/vrk ja MA->MM ja 2,5 g/vrk).

Joissain tutkimuksissa rehun la adun huononeminen loppukesällä on ollut varsin hidasta (Syrjälä ja Ojala 1978, Rinne ja Nykänen 2000) tai sulavuus on voinut jopa parantua korjuun viivästyessä (Rinne ym. 2002). Tässä kokeessa kuitenkin myös jälkikasvussa korjuun viivästyminen laski D-arvoa joskin puolet hitaammin kuin ensikasvussa. Kesällä 2002 jälkikasvun kehittyessä lämpötila oli tavalliseen syyskesään verrattuna huomattavan korkea, mikä on voinut lisätä ligniinin muodostumista ja siten huonontaa soluseinän sulavuutta. Yleensä ruohon jälkikasvumateriaalin solunseinäkuitupitoisuus on pienempi (Nousiainen 
ym. 2003) ja lehtien osuus kokonaiskuiva-aineesta suurempi (Kuoppala ym. 2003) kuin alkukesän ruohossa.

Ensi- ja jälkikasvusta korjattujen rehujen laadun vertailua vaikeuttaa se, että kasvien kehitysvaihe molemmissa sadoissa vaikuttaa suuresti rehujen koostumukseen. Rehun laadun muutoksiin vaikuttaa kasvien fysiologinen vaihe, jota voidaan kuvata lehtien ja korren suhteella. Kasvien korsiintuminen huonontaa kasvustosta tehdyn rehun D-arvoa ja lisää kuitupitoisuutta. Alkukesällä korsiintuminen on nopeaa kasvien pyrkiessä tuottamaan siemeniä. Loppukesällä korsiintuminen on hitaampaa ja siihen vaikuttavat ympäristöolot (edellisen niiton ajoitus, sää, päivän pituus). Tässä kokeessa lehtien osuus timoteistä pieneni, kun korjuu viivästyi sekä ensi- että jälkikasvussa, mutta nurminadan lehtien osuus pieneni ensikasvussa vain vähän ja pysyi jälkikasvussa korkeana. Jälkikasvu oli keskimäärin lehtevämpää kuin ensikasvu. Kasvuolosuhteiden ja korjuustrategian vaikutusten erottaminen yhden kasvukauden aikana on hankalaa, sillä molemmat vaikuttavat yhtä aikaa nurmen kehitykseen. Tästä syystä tarvitaan useamman vuoden aineisto yleisempien johtopäätösten tekemiseksi.

Parhaankaan jälkikasvurehun D-arvo ei ollut kovin korkea (664 g/kg), vaikka sen kasvuaika edellisestä niitosta oli vain 42 vrk. Tässä tutkimuksessa säilörehujen D-arvo määritettiin vakioiduissa olosuhteissa käyttäen lampaita mallieläimenä, joten eri satojen sulavuusmäärityksiin muilla menetelmillä liittyvät ongelmat vältettiin (esim. sellulaasimenetelmässä havaittu jälkikasvurehujen suurempi liukoisuus eli sulavuuden yliarviointi; Nousiainen ym. 2003). Keskikesällä korjatuissa rehuissa on erittäin harvinaista havaita korkeita sulavuuksia. Myöhemmin syksyllä korjatuissa rehuissa se on taas yleisempää. Tässä tutkimuksessa tavoitteena oli korjata kolmas sato rehujen AA ja MA jälkikasvualoilta, mutta kesän 2002 poikkeuksellisen kuumissa ja kuivissa olosuhteissa nurmi ei enää heinäkuun lopussa tehdyn niiton jälkeen lähtenyt kasvuun.

\section{Säilörehun korjuuajan vaikutus maidontuotantoon}

Lehmät söivät aikaisin korjattua ensikasvun A-rehua erittäin paljon $(17,4 \mathrm{~kg} \mathrm{ka} / \mathrm{pv}$ alemmalla väkirehutasolla) ja tuottivat runsaasti maitoa. Säilörehun D-arvon huononeminen ensikasvussa $10 \mathrm{~g} / \mathrm{kg}$ :lla vähensi lehmien säilörehun kuiva-aineen syöntiä $0,48 \mathrm{~kg}$ ja EKM:n tuotantoa $0,60 \mathrm{~kg}$ (taulukko 3). Vasteet ovat suurempia kuin kuin missään aiemmassa kokeessa. Laajan aineiston perusteella laskettuna D-arvon $10 \mathrm{~g} / \mathrm{kg}$ lasku vähensi lehmien säilörehun syöntiä $0,156 \mathrm{~kg} \mathrm{ka} / \mathrm{vrk}$ (Huhtanen ym. 2002) ja EKM-tuotosta 0,32 kg (Rinne 2000). Aikaisemmissa kokeissa lehmien pienempi maidontuotantopotentiaali ja säilörehujen vaihteleva säilönnällinen laatu ovat voineet pienentää vasteita. Tässä kokeessa väkirehun osuus rehuannoksessa oli myös varsin maltillinen (alhaisimmillaan A-rehua ja $8 \mathrm{~kg}$ väkirehua saaneilla lehmillä $28,4 \%$ ja keskimäärin $39,3 \%$ ), mikä luonnollisesti lisää säilörehun laadun muutosten vaikutusta maidontuotantoon.

Ensi- ja jälkikasvurehujen maidontuotantovaikutusten suora vertailu on hankalaa, koska kasvien kehitysvaihetta on vaikea vakioida. Lehmät söivät ensikasvun säilörehuja enemmän ja tuottivat enemmän maitoa verrattuna jälkikasvun rehuihin keskimäärin, mutta alkukesällä tehtyjen rehujen D-arvokin oli keskimäärin korkeampi. Jos verrataan ensikasvun jälkimmäistä rehua $\mathrm{M}$ ja kaikkien jälkikasvurehujen keskiarvoa, ovat rehujen keskeiset laatuparametrit varsin samanlaisia (mm. kuiva-ainepitoisuus 283 vs. 277 $\mathrm{g} / \mathrm{kg}$ ja D-arvo $644 v s .640 \mathrm{~g} / \mathrm{kg}$ ), mutta solunseinäkuitupitoisuus on ensikasvun rehussa suurempi (594 vs. $530 \mathrm{~g} / \mathrm{kg} \mathrm{ka})$. Lehmät söivät kuitenkin ensikasvun säilörehua enemmän (13,33 vs. 12,52 kg ka/vrk) ja EKM-tuotos oli suurempi (32,6 vs. 31,1 kg/vrk).

Saman kasvuston ensi- ja jälkikasvua vertailevia kokeita on tehty varsin niukasti. Heikkilän ym. (1998) kokeessa ensikasvurehun sulavuus oli hieman huonompi, mutta maitotuotos suurempi kuin jälkikasvurehua syöneiden lehmien. Vaikuttaa siis siltä, että jälkikasvusta tehtyjen rehujen syönti ja maidontuotantovaikutus ovat hieman huonompia kuin samasta kasvustosta alkukesällä tehdyn mutta muuten la adultaan vastaavan rehun. Lucasin menetelmällä määritetty solunsisällysaineiden (OM - solunseinäkuitu) todellinen sulavuus on jälkikasvusta tehdyissä rehuissa huonompi kuin alkukesän rehuissa (Huhtanen 2003).

Ensikasvu ja jälkikasvu erosivat toisistaan myös siinä suhteessa, että kasvuaste ei vaikuttanut syöntiin ja tuotokseen samalla lailla. Jälkikasvussa korjuun viivästyttäminen 14 vrk:lla ei vähentänyt säilörehun syöntiä, vaikka D-arvo huononi 50 (AA->AM) ja 35 (MA->MM) g/kg ka. Tätä vertailua vaikeuttaa se, että myöhemmin korjattujen rehujen kuiva-ainepitoisuus oli selvästi korkeampi. EKMtuotos kuitenkin väheni säilörehun D-arvon huononemisen myötä myös jälkikasvussa (taulukko 3). 


\section{Väkirehumäärän vaikutus maidontuotantoon}

Päivittäisen väkirehumäärän lisääminen $8 \mathrm{~kg}$ :sta $12 \mathrm{~kg}$ :aan vähensi kaikilla dieeteillä säilörehun kuivaaineen syöntiä. Korvaussuhde [säilörehun syönnin väheneminen (kg ka), kun väkirehuannos lisääntyi $1 \mathrm{~kg}$ ka] oli keskimäärin 0,47, mikä vastaa hyvin Suomessa aiemmin saatuja tuloksia (Huhtanen 1998). Keskimääräisissä korvaussuhteissa ensi- ja jälkikasvun rehuja syötettäessä ei ollut eroja, mutta ensikasvussa korvaussuhde oli huomattavasti suurempi hyvin sulavaa A-rehua syötettäessä kuin Mrehulla. Vaikka Rinteen ym. (1999) kokeessa säilörehun korjuuajan ja väkirehumäärän välillä ei ollut yhdysvaikutusta, laajempi kirjallisuusaineisto (Rinne 2000) tukee tässä saatua tulosta.

Väkirehuannoksen suurentaminen lisäsi maitotuotosta kaikilla säilörehuilla. Vähiten väkirehulisäys vaikutti A-säilörehua syövillä lehmillä. EKM-vaste oli keskimäärin jälkikasvurehuilla $0,92 \mathrm{~kg}$ EKM/lisätty väkirehu kg ka. Vaste oli pienempi aikaisemmin korjatuilla rehuilla sekä ensi- että jälkikasvussa (taulukko 3 ).

Eri väkirehutasoilla D-arvon muutos vaikutti eri tavoin maitotuotokseen (taulukko 3). Esimerkiksi ensikasvurehuilla energiakorjatun maidon vaste oli $0,75 \mathrm{~kg}$ EKM / $10 \mathrm{~g}$ D-arvoa, kun väkirehutaso oli 8 $\mathrm{kg}$. Kun väkirehua annettiin $12 \mathrm{~kg}$ vaste oli paljon pienempi eli 0,43 kg EKM/10 g D-arvoa.

Väkirehumäärä ei vaikuttanut orgaanisen aineen sulavuuteen, mutta NDF:n sulavuus huononi, kun väkirehuannosta lisättiin (taulukko 2).

Taulukko 3. Syönti- ja EKM-tuotosvasteet väkirehun määrän ja säilörehun D-arvon muutoksille eri rehuja syötettäessä.

\begin{tabular}{|c|c|c|c|c|c|c|}
\hline \multicolumn{7}{|l|}{ Väkirehun määrän muutos } \\
\hline & A & $\mathrm{M}$ & AA & $\mathrm{AM}$ & MA & MM \\
\hline Korvaussuhde $^{1)}$ & 0,71 & 0,22 & 0,53 & 0,43 & 0,42 & 0,54 \\
\hline kg EKM / kg väkirehun ka & 0,34 & 0,90 & 0,76 & 0,97 & 0,86 & 1,07 \\
\hline \multicolumn{7}{|c|}{ Säilörehun D-arvon muutos (ilmoitettu $10 \mathrm{~g} / \mathrm{kg}$ muutosta kohti) } \\
\hline & $\mathrm{A}->\mathrm{M}$ & & $\mathrm{AA}->\mathrm{A}$ & & MA->M & \\
\hline Säilörehun syönti, kg ka/pv & 0,48 & & 0,00 & & 0,00 & \\
\hline \multirow[t]{3}{*}{$\mathrm{EKM}, \mathrm{kg} / \mathrm{pv}$} & 0,61 & & 0,14 & & 0,46 & \\
\hline & \multicolumn{2}{|c|}{$A->M$} & \multicolumn{2}{|c|}{ AA->AM } & \multicolumn{2}{|c|}{ MA->MM } \\
\hline & $8 \mathrm{~kg}$ & $12 \mathrm{~kg}$ & $8 \mathrm{~kg}$ & $12 \mathrm{~kg}$ & $8 \mathrm{~kg}$ & $12 \mathrm{~kg}$ \\
\hline Säilörehun syönti, kg ka/pv & 0,63 & 0,36 & 0,05 & $-0,02$ & $-0,03$ & 0,08 \\
\hline $\mathrm{EKM}, \mathrm{kg} / \mathrm{pv}$ & 0,75 & 0,43 & 0,25 & 0,10 & 0,55 & 0,36 \\
\hline
\end{tabular}

${ }^{1)}$ Säilörehun syönnin väheneminen (kg ka), kun väkirehuannos lisääntyi 1 kg ka

\section{Johtopäätokset}

Tämän kokeen tulokset tukevat käsitystä, että ensikasvusta tehdyn säilörehun tuotantovaikutus on hieman parempi kuin muuten laadultaan vastaavan, mutta nurmen jälkikasvusta tehdyn säilörehun. Säilörehun Darvon lasku vähensi maitotuotosta selvemmin, kun lehmille syötettiin ensikasvurehua. Väkirehuannoksen suurentaminen lisäsi maitotuotosta enemmän, kun säilörehun sulavuus oli huonompi.

Säilörehun laadulla on siis selkeä vaikutus lehmien maidontuotantoon ja muun muassa tietyn tuotoksen saavuttamiseen tarvittavan väkirehumäärän tarpeeseen. Tämän kokeen perusteella ei voi kuitenkaan suositella tiettyä korjuustrategiaa. Kesän 2002 poikkeukselliset sääolosuhteet ovat voineet vaikuttaa erityisesti jälkikasvurehujen laadun kehitykseen. Lisäksi eri korjuustrategioiden vaikutuksia lypsykarjatilan taloudelliseen tulokseen pitäisi tarkastella laajasti yksittäisen tilan omien tuotanto-olosuhteiden puitteissa. Korjuustrategian valinta tilalla riippuu $\mathrm{mm}$. käytettävissä olevasta nurmialasta, lehmämäärän joustomahdollisuuksista, väkirehun ruokintastrategiasta jne. 


\section{Kirjallisuus}

Heikkilä, T., Toivonen, V. \& Huhtanen, P. 1998. Effect of spring and autumn silage, protein and concentrate level on milk production. Eds. Nagy, G. \& Petö, K. Proceedings of the $17^{\text {th }}$ General meeting of the European Grassland Federation "Ecological aspects of grassland management". P.717-721.

Huhtanen, P. 1998. Supply of nutrients and productive responses in dairy cows given diets based on restrictively fermented silage. Agricultural and Food Science in Finland 7: 219-250.

Huhtanen, P. 2003. Factors influencing on voluntary intake of silage-based diets, and responses of silage quality in milk production. Proceedings of the International Symposium "Early harvested forage in milk and meat production", 23-24 October 2003, Kringler, Nannestad, Norway. Editor Torstein H. Garmo. Agricultural University of Norway, Department of Animal and Aquacultural Sciences, Ås, Norway. pp. 44-58. ISBN 82-7479-0162.

Huhtanen, P., Khalili, H., Nousiainen, J.I., Rinne, M., Jaakkola, S., Heikkilä, T. \& Nousiainen, J. 2002. Prediction of the relative intake potential of grass silage by dairy cows. Livestock Production Science 73: 111130.

Kuoppala, K., Rinne, M. \& Huhtanen, P. 2003. Morphological composition and digestibility of primary growth and regrowth of timothy. In: Oiva Niemeläinen and Mari Topi-Hulmi (eds.). Proceedings of the NJF's 22nd congress 'Nordic Agriculture in Global Perspective', July 1-4, 2003, Turku, Finland. Jokioinen: MTT Agrifood Research Finland, NJF. [p. 15]. http://portal.mtt.fi/pls/portal30/docs/FOLDER/AGRONET/YHTEIS ET_HANKKEET/NJF/NJF2003/2.PDF Published 15.9.2003

Nousiainen, J., Rinne, M., Hellämäki, M. \& Huhtanen, P. 2003. Prediction of the digestibility of primary growth and regrowth grass silages from chemical composition, pepsin-cellulase solubility and indigestible cell wall content. Animal Feed Science and Technology 110: 61-74.

Rinne, M. 2000. Influence of the timing of the harvest of primary grass growth on herbage quality and subsequent digestion and performance in the ruminant animal. University of Helsinki, Department of Animal Science. Publications 54. 42 p. +5 encl. Academic dissertation. Available at:

http://ethesis.helsinki.fi/julkaisut/maa/kotie/vk/rinne.

Rinne, M., Huhtanen, P. \& Nousiainen, J. 2002. Rehunurmen jälkikasvun kehitykselle malli. Maataloustieteen Päivät 2002. Kotieläintiede. Maaseutukeskusten Liiton julkaisuja 977. Toim. M. Rinne. pp. 79-81.

Rinne, M. \& Nykänen, A. 2000. Timing of primary growth harvest affects the yield and nutritive value of timothy-red clover mixtures. Agricultural and Food Science in Finland 9: 121-134.

Tuori, M., Kuoppala, K., Valaja, J., Aimonen, E., Saarisalo, E. \& Huhtanen, P.2002. Rehutaulukot ja ruokintasuositukset 2002 [verkkodokumentti]. Jokioinen: MTT. Julkaistu 28.6.2002, [viitattu 9.12.2003]. Saatavissa: http://www.agronet.fi/rehutaulukot/. URN:NBN:fi-fe20011096. 
Taulukko 2. Säilörehun korjuustrategian vaikutus lehmien rehujen syöntiin, ravintoaineiden sulavuuteen ja tuotantoon.

\begin{tabular}{|c|c|c|c|c|c|c|c|c|c|c|c|c|c|c|c|c|c|c|c|}
\hline \multirow{3}{*}{$\begin{array}{l}\text { Korjuupäivä } \\
\text { SR }\end{array}$} & \multirow{2}{*}{\multicolumn{2}{|c|}{$\frac{1 . \text { sato A }}{5.6 .2002}$}} & \multirow{2}{*}{\multicolumn{2}{|c|}{$\frac{1 . \text { sato M }}{17.6 .2002}$}} & \multicolumn{4}{|c|}{ 2.sato A:n jälkikasvu } & \multicolumn{4}{|c|}{ 2.sato M:n jälkikasvu } & \multirow{4}{*}{ SEM } & \multicolumn{6}{|c|}{ Tilastollinen merkitsevyys, kontrastit } \\
\hline & & & & & \multicolumn{2}{|c|}{ 29.7.2002 } & \multicolumn{2}{|c|}{12.8 .2002} & \multicolumn{2}{|c|}{ 29.7.2002 } & \multicolumn{2}{|c|}{12.8 .2002} & & \multirow[b]{3}{*}{ Vr-taso } & \multirow[b]{3}{*}{ A vs. M } & \multirow{3}{*}{$\begin{array}{l}\text { 1. sato } \\
\text { vs. } \\
\text { 2. sato }\end{array}$} & \multirow{3}{*}{$\begin{array}{c}\mathrm{AA}+\mathrm{AM} \\
v s . \\
\mathrm{MA}+\mathrm{MM}\end{array}$} & \multirow{3}{*}{$\begin{array}{c}\text { AA } v s . \\
\text { AM }\end{array}$} & \multirow{3}{*}{$\begin{array}{c}\text { MA vs. } \\
\text { MM }\end{array}$} \\
\hline & A & A & M & M & AA & AA & $\mathrm{AM}$ & $\mathrm{AM}$ & MA & MA & MM & MM & & & & & & & \\
\hline VR-taso, kg & 8 & 12 & 8 & 12 & 8 & 12 & 8 & 12 & 8 & 12 & 8 & 12 & & & & & & & \\
\hline \multicolumn{20}{|c|}{ Rehujen syönti, kg ka/pv } \\
\hline Säilörehu & 17,4 & 15,0 & 13,8 & 12,9 & 13,0 & 11,4 & 12,9 & 11,7 & 13,7 & 11,9 & 13,7 & 11,8 & 0,18 & $* * *$ & $* * *$ & $* * *$ & $* *$ & & \\
\hline Väkirehu & 6,9 & 10,2 & 6,9 & 10,3 & 6,9 & 10,3 & 6,9 & 10,3 & 6,9 & 10,4 & 6,9 & 10,3 & 0,01 & & & & & & \\
\hline Yhteensä & 24,3 & 25,3 & 20,7 & 23,2 & 19,9 & 21,7 & 19,7 & 22,0 & 20,6 & 22,3 & 20,6 & 22,2 & 0,18 & $* * *$ & $* * *$ & $* * *$ & $* *$ & & \\
\hline \multicolumn{20}{|c|}{ Ravintoaineiden saanti, kg/pv } \\
\hline Orgaaninen aine & 22,2 & 23,2 & 19,2 & 21,5 & 18,1 & 19,7 & 18,0 & 20,1 & 18,7 & 20,3 & 18,9 & 20,3 & 0,17 & $* * *$ & $* * *$ & $* * *$ & $* *$ & & \\
\hline NDF & 10,4 & 10,1 & 10,0 & 10,3 & 8,7 & 8,7 & 8,7 & 8,9 & 8,9 & 8,8 & 9,0 & 8,9 & 0,10 & & & $* * *$ & & & \\
\hline $\mathrm{ME}, \mathrm{MJ} / \mathrm{pv}^{1)}$ & 260 & 265 & 205 & 226 & 208 & 230 & 196 & 222 & 218 & 238 & 215 & 231 & 2,49 & $* * *$ & $* * *$ & $* * *$ & $* * *$ & $* *$ & o \\
\hline $\mathrm{ME}, \mathrm{MJ} / \mathrm{pv}^{2)}$ & 285 & 302 & 232 & 264 & 224 & 248 & 218 & 248 & 235 & 259 & 233 & 254 & 1,86 & $* * *$ & $* * *$ & $* * *$ & $* * *$ & & o \\
\hline \multicolumn{20}{|c|}{ Ravintoaineiden sul avuus ${ }^{3)}$} \\
\hline Orgaaninen aine & 737 & 709 & 668 & 658 & 720 & 725 & 684 & 696 & 732 & 733 & 704 & 710 & 8,9 & & $* * *$ & $* *$ & o & $* *$ & $*$ \\
\hline Raakavalkuainen & 687 & 663 & 647 & 636 & 685 & 684 & 621 & 627 & 688 & 688 & 640 & 653 & 10,6 & & $*$ & & & $* * *$ & $* *$ \\
\hline NDF & 665 & 596 & 572 & 520 & 650 & 622 & 582 & 551 & 680 & 642 & 625 & 586 & 12,5 & $* * *$ & $* * *$ & $* *$ & $* *$ & $* * *$ & $* *$ \\
\hline \multicolumn{20}{|l|}{ Tuotos } \\
\hline Maito kg/pv & 32,2 & 33,8 & 28,9 & 32,4 & 28,1 & 30,5 & 27,2 & 30,6 & 30,3 & 32,9 & 28,0 & 31,6 & 0,53 & $* * *$ & $* *$ & $* * *$ & $* *$ & & $* *$ \\
\hline EKM kg/pv & 35,4 & 36,6 & 30,9 & 34,0 & 29,3 & 31,9 & 28,0 & 31,4 & 31,0 & 34,0 & 29,1 & 32,7 & 0,54 & $* * *$ & $* * *$ & $* * *$ & $* *$ & & $*$ \\
\hline Rasva g/pv & 1517 & 1524 & 1313 & 1400 & 1219 & 1322 & 1161 & 1286 & 1273 & 1384 & 1208 & 1330 & 25,5 & $* * *$ & $* * *$ & $* * *$ & $*$ & & o \\
\hline Valkuainen $\mathrm{g} / \mathrm{pv}$ & 1104 & 1179 & 939 & 1079 & 917 & 1005 & 874 & 992 & 981 & 1081 & 901 & 1045 & 18,4 & $* * *$ & $* * *$ & $* * *$ & $* *$ & & $*$ \\
\hline Laktoosi g/pv & 1557 & 1645 & 1418 & 1594 & 1356 & 1479 & 1321 & 1490 & 1466 & 1623 & 1367 & 1560 & 30,0 & $* * *$ & $*$ & $* * *$ & $* *$ & & $*$ \\
\hline \multicolumn{20}{|c|}{ Maidon koostumus, g/kg } \\
\hline Rasva & 47,2 & 45,3 & 45,7 & 43,3 & 43,6 & 43,7 & 42,7 & 42,1 & 42,0 & 42,4 & 43,4 & 41,9 & 0,68 & $*$ & o & $* * *$ & & & \\
\hline Valkuainen & 34,3 & 35,1 & 33,0 & 33,7 & 33,0 & 33,3 & 32,2 & 32,7 & 32,6 & 33,1 & 32,4 & 33,1 & 0,26 & $* *$ & $* * *$ & $* * *$ & & $*$ & \\
\hline Laktoosi & 48,5 & 48,6 & 49,1 & 49,2 & 48,2 & 48,4 & 48,6 & 48,8 & 48,4 & 49,3 & 48,8 & 49,4 & 0,20 & $*$ & $*$ & & $*$ & & \\
\hline Urea, mg/100ml & 25,2 & 25,6 & 22,9 & 26,6 & 29,8 & 28,0 & 18,6 & 22,2 & 31,3 & 30,9 & 23,8 & 24,3 & 0,65 & $*$ & & $*$ & $* * *$ & $* * *$ & $* * *$ \\
\hline Elopaino & 636,5 & 635,8 & 625,4 & 638 & 626 & 631 & 628 & 630 & 625 & 627 & 628 & 631 & 2,9 & o & & $*$ & & & \\
\hline Elop. muutos kg/pv & 0,78 & 0,92 & $-0,51$ & 0,42 & $-0,45$ & 0,28 & $-0,13$ & 0,41 & $-0,28$ & 0,24 & 0,02 & 0,06 & 0,182 & $* * *$ & $* * *$ & $* *$ & & & \\
\hline
\end{tabular}

1) ME-saanti laskettu AIA:Ila määritetyn sulavan orgaanisen aineen perusteella. ${ }^{2)}$ ME-saanti laskettu in vivo D-arvon perusteella. ${ }^{3)}$ Määritetty AIA:lla 